\title{
Medidor de grados Brix en Uvas
}

\section{Grape Brix Meter}

\author{
ARELLANO-YAÑEZ, Ricardo*†, LOPEZ-REYES, Fernando Octavio y DOMÍNGUEZ-LÓPEZ, Rene \\ Félix
}

Universidad Tecnológica del Norte de Aguascalientes

ID $1^{\mathrm{er}}$ Autor: Ricardo, Arellano-Yañez/CVU CONACYT ID: 688402

ID $1^{\text {er }}$ Coautor: Fernando Octavio, Lopez-Reyes/ CVU CONACYT ID: 274438

ID 2 ${ }^{\mathrm{do}}$ Coautor: Rene Félix, Domínguez-López/CVU CONACYT ID: 299393

DOI: $10.35429 /$ JOTI.2019.10.3.22.24

Recibido 11 de Abril, 2019; Aceptado 17 de Junio, 2019

\begin{abstract}
Resumen
Contribución: El medidor de grados brix tiene la finalidad de usarlo en campo y laboratorio para recolectar la información correspondiente a este parámetro (grados brix) para muestrear los cultivos de hortalizas, frutales y principalmente uvas que se tienen en los viñedos de la Universidad Tecnológica del Norte de Aguascalientes, poder dar seguimiento a los grados de madures de las uvas asi como de las parras de estos viñedos mediante la recolección de datos y análisis incluso poder decidir en base a los resultados de grados brix tomados y analizados por el medidor el cosechar este producto en el mejor momento. Objetivos: Desarrollar un medidor de grados brix para uso tanto didáctico como profesional, que permita muestrear en campo este parámetro en las plantas y principalmente en el fruto de los viñedos de la Universidad Tecnológica del Norte de Aguascalientes como en la región circundante de la misma para monitorear el grado de madurez de los cultivos y así determinar la mejor temporalidad de cosecha de las uvas en base a análisis de datos procurando obtener el mejor producto para la producción de vinos de mesa. Metodología: Se habrá de considerar el método de refracción de luz y también por conductividad para desarrollar el dispositivo para medir los grados brix, ya que son un métodos simples y de uso común, se hará el procesamiento electrónico de la muestra en el mismo aparato haciendo una comparación de parámetros de acuerdo con la escala determinada para los diferentes tipos de uva que se quiere monitorear, se almacenara los datos de un numero de muestras y se hará los cálculos estadísticos necesarios que arrojaran el resultado y sugerirá en base a estos el momento idóneo de cosecha, dichos datos podrán ser descargados en una base de datos para su historial y monitoreo en laboratorio.
\end{abstract}

\begin{abstract}
Resumen
Contribution: The brix degree meter has the purpose of using it in the field and in the laboratory to collect the information corresponding to this parameter (brix degrees) to sample the crops of vegetables, fruit trees and mainly grapes that are held in the vineyards of the Technological University of North of Aguascalientes, being able to monitor the ripeness of the grapes as well as the grapevines of these vineyards through data collection and analysis, and even decide based on the results of brix grades taken and analyzed by the meter to harvest this product at the best time. Objectives: To develop a brix degree meter for both didactic and professional use, which allows us to sample this parameter in the field in the plants and mainly in the fruit of the vineyards of the Technological University of the North of Aguascalientes and in the surrounding region of the same for monitor the degree of maturity of the crops and thus determine the best seasonality of harvesting the grapes based on data analysis trying to obtain the best product for the production of table wines. Methodology: The light refraction method and also for conductivity should be considered to develop the device to measure the brix degrees, since they are a simple and commonly used methods, the electronic processing of the sample in the same device will be done a comparison of parameters according to the scale determined for the different types of grapes that you want to monitor, the data of a number of samples will be stored and the necessary statistical calculations will be made that will yield the result and will suggest in based on these the ideal time of harvest, said data may be downloaded in a database for its history and laboratory monitoring.
\end{abstract}

Meter - Brix - Grape

Medidor - Brix - Uva

Citación: ARELLANO-YAÑEZ, Ricardo, LOPEZ-REYES, Fernando Octavio y DOMÍNGUEZ-LÓPEZ, Rene Félix. Medidor de grados Brix en Uvas. Revista de Invención Técnica 2019. 3-10:22-24

*Correspondencia al Autor (Correo Electrónico: ricardo.arellano@utna.edu.mx)

$\uparrow$ Investigador contribuyendo como primer autor. 


\section{Introducción}

Un parámetro de monitoreo de la madurez de las uvas es el nivel de grados Brix que contiene y con esto se puede determinar también el buen sabor de estas.

En si el parámetro de grados Brix sirve para medir el dulzor que tienen las frutas o verduras, por tanto, entre mayor sea la cantidad de grados Brix mayor dulzura habrá en la muestra.

Un ejemplo de este parámetro es si se tiene $25{ }^{\circ} \mathrm{Bx}$ (grados Brix) significa que tienes 25 gramos de 100 gramos totales de solución, con esto diríamos que si sale un nivel alto de ${ }^{\circ} \mathrm{Bx}$ quiere decir que tiene muchos solidos con respecto al total, los cuales pueden ser azucares disueltos y de ahí el sabor dulce o no.

En otras palabras, el cociente total de sacarosa o sal disuelta en un líquido, es la concentración de sólidos- solubles. En el ejemplo anterior sería así: contiene $25 \mathrm{~g}$ de azúcar (sacarosa) por $100 \mathrm{~g}$ de líquido, en $100 \mathrm{~g}$ de solución hay $25 \mathrm{~g}$ de sacarosa y $75 \mathrm{~g}$ de agua". También los ${ }^{\circ} \mathrm{B}$ sirven $\mathrm{o}$ es un medio para determinar el punto óptimo de recolección de producto.

Otra ventaja de este parámetro es ofrecer información in situ sobre la planta y determinar si se esta alimentando bien, en otras palabras, si se logra extraer la savia del cultivo a través de sus hojas y dicha savia se puede pasar por el medidor de grados brix y examinar este parámetro para establecer si la planta está en buenas condiciones.

Se desarrollará este analizador con ambos métodos de refracción y conductividad buscando dar funcionalidad por ambos métodos e incluso se podrá hacer la comparación de ambas mediciones y determinar una mayor precisión de la medición realizada.

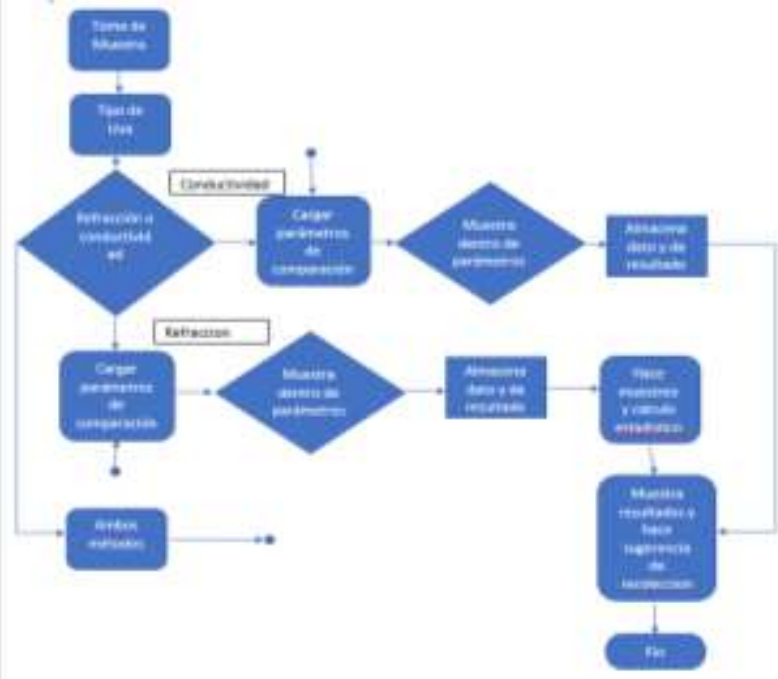

Figura 1 Diagrama de flujo de metodología para funcionamiento de medidor de grados Brix

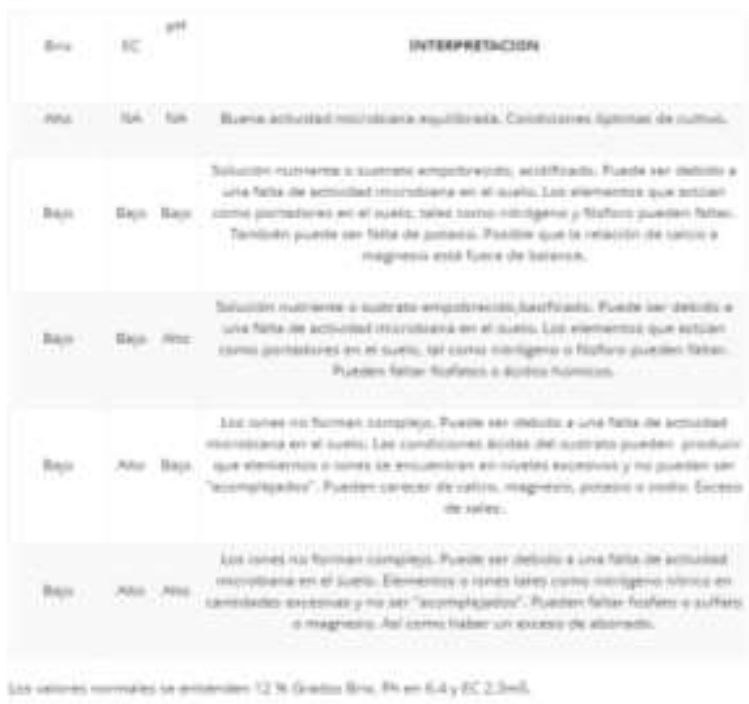

Tabla 1 Tabla Patrón para interpretación de la evolución del cultivo en grados brix

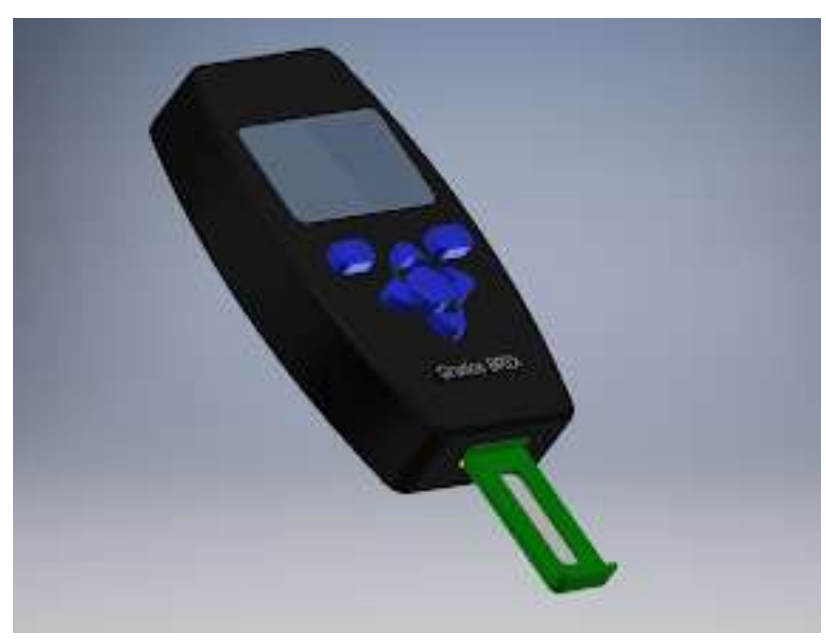

Figura 2 Forma física propuesta del dispositivo 
Con el dispositivo propuesto se piensa ofrecer a la Universidad Tecnológica del Norte de Aguascalientes un medidor para hacer los muestreos y análisis en situ y en laboratorio de las muestras de uvas que se usaran para la producción de vinos de mesa, buscando desde el cultivo el desarrollo de productos de calidad que logren dar un buen posicionamiento a estos productos y hacer en conjunto con las carreras de vitivinicultura y mantenimiento industrial un proyecto integrador que sirva incluso para buscar el análisis de otros productos.

Es importante mencionar que este medidor será un desarrollo para uso de la Universidad Tecnológica del Norte de Aguascalientes en primera instancia y con el tiempo se pudiera proponer para el desarrollo de más dispositivos para otras instituciones.

\section{Metodología a desarrollar}

La metodología que se está siguiendo en este proyecto es en base a los datos proporcionados por el área de vitivinicultura respecto a lo que se debe monitorear así como los parámetros de comparación y buscando las metodologías actuales de análisis de grados brix, buscando realizar un medidor que integre las opciones de análisis por refracción y conductividad así como la toma de datos, su comparación, análisis, muestreo y procesamiento, con la finalidad que dichos análisis brinden una toma de decisiones en base a datos y no solo con el expertis de los usuarios.

\section{Resultados}

Hasta el momento el resultado obtenido es la propuesta teórica y digital para el desarrollo de un medidor de grados brix $\left({ }^{\circ} \mathrm{Bx}\right)$, además se está desarrollando el algoritmo correspondiente para el software operacional y la selección del hardware correspondiente para brindar la confiabilidad en el uso de este medidor.

\section{Anexos}

\section{Agradecimiento}

Se agradece el apoyo otorgado, a el área de vitivinicultura durante desarrollo de este medidor, así como a la Universidad Tecnológica del Norte de Aguascalientes por parte de sus autoridades correspondientes

\section{Conclusiones}

El medidor que se obtendrá será en base a lo propuesto, siendo este un medidor necesario para el uso en el monitoreo de los viñedos de la Universidad Tecnológica del Norte de Aguascalientes, para ofrecer productos de alta calidad desde sus cultivos.

\section{Referencias}

NMX-Z-013-1977. Guía para Redacción, Estructuración y Presentación de las Normas Mexicanas., NMX-F-103-1965. Norma Oficial de Método de Prueba para la Determinación de "Grados Brix.

https://agriculturers.com/que-son-los-gradosbrix/

http://www.elbruixot.com/semillasdemaria/grad os-brix-el-secreto-de-una-planta-bienalimentada/

https://www.colpos.mx/bancodenormas/nmexic anas/NMX-F-103-1982.PDF

http://www.cndsca.gob.mx/eficienciaproductiva /normas/2013/NMX-f-436-SCFI-2011.pdf 